\title{
How Portugal became an 'unplanned country': A critique of scholarship on Portuguese urban development and planning
}

\author{
Idalina Baptista \\ (idalina.baptista@sbs.ox.ac.uk), Sir Nigel Mobbs Research Fellow, Oxford Programme \\ for the Future of Cities, Institute for Science, Innovation and Society, University of \\ Oxford, Park End Street, Oxford OX1 1HP, UK.
}

\section{Disorder and the Experience of Modernity}

How can a country be 'disordered'? Order - particularly spatial order - is often invoked in the recent history of cities as an underlying value of modern societies. Various authors have documented the fixation of late nineteenth and early twentieth-century reformers in Germany, France, the U.K. or the U.S. with the need to spatially discipline cities in order to support industrial and commercial development and a particular notion of civilization (e.g. Boyer, 1983; Hall, 2000; Ward, 2002). Scholars have now challenged this so-called EuroAmerican (Roy, 2009) hegemonic view of spatial order as a proxy for modernity, development and progress. They have parochialized its universalism and identified its pernicious effects, particularly in nations subject to the diverse European colonial projects (e.g. Sennett, 1970; Scott, 1998; Chakrabarty, 2000; Sandercock, 2003; Robinson, 2006; Roy, 2009).

Portuguese urban scholarship has remained largely impervious to the debates in urban and social theory in which modernity and its proxies are being questioned. This is an understandable positioning considering that most of such discussion emerged with studies in postcolonialism vying for alternative understandings of modernity. As a European country, with its own colonial past and a longstanding claim to the making of world history, it is seemingly unreasonable that scholarship on Portugal would undermine the so-called EuroAmerican view of modernity. However, scholarship has consistently offered a view of the Portuguese city as struggling to achieve this model, in part owing to a sense of the country's semi-peripheral condition (Santos, 1994). Borrowing Chakrabarty's "not yet" (2000: 8) quip for how nineteenth-century Europeans cast non-Europeans, scholars portray the Portuguese city as 'not quite yet' modern and civilized as other 'First World' cities.

The idea that Portugal is an 'unplanned country' - a product of disorderly growth embodies precisely this paradoxical view of the Portuguese city. In this article, I seek to expose how Portuguese urban scholarship uses the 'unplanned country' idea as a way to organize intellectually and discursively the experience of modernity, urban growth and social transformation throughout the twentieth-century. I do this through a review of scholarly accounts about the problem-ridden Portuguese city since the 1930s.[1] This review is not exhaustive. Instead, it targets key authors recognized by their prominence and contribution to contemporary Portuguese scholarship. 
Understanding how scholars characterize the idea of the 'unplanned country' and how it came about is important not so much for its arguably accurate depiction of the Portuguese urban condition, but because this idea has provided us with a selective view of the problems of the Portuguese city and how to tackle them (Hajer, 1993; Rein and Schön, 1993; Gunder and Hillier, 2009). In this article, I examine what the 'unplanned country' idea stands for and its theoretical and empirical underpinnings as a way to recognize its powerful organizing capacity. I also offer a preliminary research agenda that brings Portuguese urban scholarship closer to current urban and social theory debates. These are necessary steps towards a deeper understanding of the Portuguese city and of the impacts the 'unplanned country' idea has had in urban policies, planning practices and city livelihoods.

Scholars use the 'unplanned country' idea to signal a perceived divergence between the concrete experience of the Portuguese city and the idealized spatial and political order of the so-called EuroAmerican city model (see next section). In theory, the achievement of the model depended not just on the presence of an adequate state apparatus, but also on a cadre of professionals with the appropriate scientific knowledge and expertise: planners, engineers, architects, economists and other educated professionals. Their views of order, and the methods to achieve it, have since become embodied in techniques of governance, laws of the state and professional practices and disciplines (Rabinow and Rose, 1994). In so doing, this model offers us a social structure in which the division of roles, responsibility and accountability between state, market and civil society are made clear and certain, despite their actual idiosyncrasies and overlaps. They lead us to believe that certain normative views of the 'good' city are universal and desirable. They bind us in a collective identity and purpose (Gunder and Hillier, 2009: 29): to become modern and developed and to enjoy the benefits of orderly development.

Unfortunately, Portuguese scholarship has been short of recognizing the selectiveness of the modernity narrative and engaging with critiques in urban and social theory about its views of order, planning, expertise and the state (see third section). Also in wanting is an empirical and theoretical questioning of how the idea of the 'unplanned country' connects with the emergence of a scholarly and professional planning field. Such an inquiry could shed light on the enduring and pervasive impact of the idea of 'disorder' in organizing decades of Portuguese urban policy and its consequent impacts on cities. Moreover, it requires overcoming the empirical and methodological shortcomings that contributed to crystallize the 'not quite yet' attitude found in Portuguese scholarship (see fourth section). Unless we pursue further research that theoretically and empirically deepens our knowledge of the Portuguese city, the 'unplanned country' idea will continue to constrain a deeper understanding of the Portuguese urban experience (see fifth section).

Offering a critique of representations of 'not quite yet' modern cities of a former European colonizer unsettles the 'EuroAmerican experience' category found in current critiques of urban theory production. In a recent article, Ananya Roy masterfully articulated new geographies of urban theory by dislocating the "EuroAmerican centre of theoretical production" (2009: 820) to the cities of the Global South. In her view, we must "blast open theoretical geographies" (ibid.: 820) and move beyond the EuroAmerican city experience, if we are to command "an analysis of the heterogeneity 
and multiplicity of metropolitan modernities" (ibid.: 821). Paraphrasing Roy, I suggest that a look into the Portuguese city 'blasts open' the very idea of an all-encompassing 'EuroAmerican experience' that her article suggests. It acknowledges the existence of a set of persistently silenced 'Euro'-experiences with 'heterogeneous modernities', a move that may further parochialize existing urban theory. Perhaps more importantly, it highlights how, by fate of its geographical focus, scholarship produced on these 'Euro' cities has been intuitively eclipsed from the new repertoires advocated by Roy. Revealing how the urban experiences of these cities have been broadly imagined can also enrich the much-needed effort of epistemological renewal that animates current international planning debates.

\section{The idea of the 'unplanned country': chaos, disorder and underdevelopment}

If there is a topic regularly mobilized to assess normative views of the 'good' city is that of commuter traffic. In a recent documentary TV series, António Barreto, a renowned Portuguese sociologist, deploys traffic conditions in the Lisbon Metropolitan Area to illustrate the difficult livelihood conditions in contemporary Portuguese cities (Barreto and Pontes, 2007).[2] The story begins with Barreto reporting in voice off: "It's eight in the morning. In the roads of my country, I [see] the image of a people eternally belated. A disorganized country is portrayed at the entrance of cities. At night, on the way home, I see an irremediably tired people. There is no economist, nor a mathematician, capable of calculating the damage this represents. This is how we waste our lives."

The derogatory tone of expressions such as 'eternally belated,' 'disorganized' or 'waste our lives' continues throughout the documentary. Barreto traces the origins of the bleak Portuguese urban condition back to the $1960 \mathrm{~s}$. Before then, he tells the viewer, most people lived in the countryside in hardship and poverty. The existing cities were small and unconnected. In the eyes of Barreto, these cities must have been ordered and organized, because he claims that it was the fast-paced growth of the late 1960s that "brought disorder with it." As an outcome, he concludes with dismay, "[a]n ugly and difficult country was born." To illustrate the "ugliness', Barreto recalls the plight of slums, shanty towns and clandestine settlements[3] that took over the Lisbon Metropolitan Area up to the 1980s. He also caricatures the arguably inverted process of Portuguese urban development: "First, cities grew. Afterwards, plans were made. Housing is built, and most of the time, access roads, public spaces, power lines, gas, and sewage infrastructures are completed only after people move in. Services, such as education and health [services], roll out at the end, and almost always only after that [does] public transit [comes in]." Seemingly unaware of the pervasive shortcomings of planning urban development in many capitalist societies, Barreto points to the incapacity, condescendence or unwillingness of local and central governments to cope with the pressures of a dysfunctional housing market through planning. To conclude the documentary, while exhorting the modern ideal of city living, Barreto sums up the livelihood conditions in Portuguese cities with two statements: "It is in the city that the aspirations of the modern world are born and satisfied. But it is difficult to live in these Portuguese cities." 
I make the point in quoting Barreto extensively because his portrayal of contemporary Portuguese cities encapsulates many of the elements of the idea of Portugal as an 'unplanned country'. Through Barreto's hindsight, we see contemporary Portuguese cities as disorganized, mired with persistent infrastructural problems and lacking in environmental amenities required for the social and emotional well-being of modern citizens. The cause of such a deficient quality of life in cities, Barreto argues, is the lack of planning or, in a personified version, the inability of state agents to plan for and manage urban development over the last decades. Implicit in his characterization is the understanding that the Portuguese city is 'not quite yet' like the unnamed ideal city: the planned and ordered city of the developed, 'First World' countries.

Barreto is not alone in his bleak reading of Portuguese urban development and in the use of derogatory terms to qualify it. Many scholars, policymakers, practitioners and opinion-makers share similar views and use similar language. Francisco Nunes Correia, an academic who recently led an urban regeneration program under the Ministry of Environment - the Polis Program - claimed its objective was to "[p]rovide examples of correction of urban mistakes" (2003: 12) made in past urban development. Through its regeneration projects, the program would "bring quality, good architecture, a touch of cosmopolitanism, respectful of tradition, to cities across the country" (ibid.: 16). Luísa Schmidt (1999; 2007), a sociologist well known for her environmental awareness work, has penned many incisive commentary-style accounts of 'unplanned' development around the country, reckoning the chaos and environmental degradation of coastal urbanization or the proliferation of anarchic suburbs. António Fonseca Ferreira, a top public official working in planning-related government agencies since the 1970s and longstanding director of a journal on urban issues, corroborates similar views. In a 1999 editorial to his journal, he claims that " $t \mathrm{t}]$ he urbanization of Portuguese society has proceeded in a totally uncontrolled fashion" (Ferreira, 1999: 4). In another editorial piece, he takes out on city suburbs, qualifying these "disorderly peripheries" as "ugly and melancholic, built to house people, but where all that is needed to inhabit and live is missing" (Ferreira, 2000: 4). Luís Bruno Soares, a practitioner and consultant with decades of involvement in high profile planning studies and projects, contrasts what he sees to be the European model of concentrated urban growth to the "unavoidable reality of dispersion" of Portuguese urban development (Soares, 2002: 125). While he acknowledges that 'dispersion' as a pattern of urbanization also occurred elsewhere, he claims that the "other more organized European countries" (ibid.: 125) planned for their dispersed urban development.

Soares might be right in his assertion. But if we accept his observations at face value, then we must confront his views of the Portuguese experience with the reality of unplanned suburbanization in the 'more organized countries' of North America (Harris, 1999; Loeb, 2002; Nicolaides, 2002) or, more close to home, the French bidonville phenomena (Hervo and Charras, 1971; Gastaut, 2004). Bearing in mind that the idea of the 'unplanned country' has a powerful selective organizing capacity, I propose instead that we examine what these and other authors think the problems of the Portuguese city are and what causes them. 


\section{Putting the 'lack' into perspective: bringing urban theory to the 'unplanned country'}

In their discussions of planning's overarching concepts as master (or empty) signifiers, Gunder and Hillier (2009: 29-30) argue that when an ideal is expressed as a 'lack' (e.g. of order, global competitiveness or sustainability) it becomes a powerful tool in shaping urban policies and plans and, consequently, the daily lives of our communities. They note that one of the "constituting fantasies" of planning is that it can address that 'lack' because it "successfully provides the solutions necessary in order to provide certainty and harmony" (ibid.: 31) to our cities, supported on the advice of "unbiased, rational, scientific technical experts serving the public interest" (ibid.: 33).

I find Gunder and Hillier's insight useful to exposing three problematic ways through which scholars construct the 'unplanned country' idea. First, it draws attention to the fallacy that the perceived disorder is a result of a lack of planning and, consequently, a lack of conditions for modernity. Second, it brings out the insufficient engagement of Portuguese scholarship with relevant research and debates in urban studies. Finally, it allows us to examine the emergence of the 'unplanned country' idea in the context of the formation of scholarly and professional elites claiming the adequate expertise to diagnose and fix the 'disorder' of the Portuguese city.

\subsection{The 'lack of planning' fallacy}

The lack of formal planning is at the heart of the idea of Portugal as an 'unplanned country' (Gonçalves, 1986, 1989; Salgueiro 1992; Correia, 1993; Silva 1993; Carter and Silva, 2001; Lobo, 2001; Pires, 2001, 2005; Ferreira, 2005; Balsas, 2006). Scholars usually trace the lack of formal, legally binding plans back to the dictatorship period (1926-1974), when the first modern planning legislation appeared (the 1934 General Urbanization Plan Act). Scholars tend to note the persistence of the situation after the 1974 revolution and up to 1986, when Portugal accessed the European Economic Community (EEC, today the European Union). The general view is that formal legally binding plans only emerged by the end of the 1990s, taking on the outdated form of physical, blueprint planning.

Often cited for his work on the history of Portuguese urban legislation, Gonçalves (1986, 1989) suggests that during the dictatorship, most cities had no legally binding instruments through which to enforce provisions for urban development. Carter and Silva (2001: 341) note that the lack of mandatory planning outside existing urban areas until the 1980s induced "extensive uncoordinated development, a lack of community facilities and a chaotic transport system". Pires (2001: 184-185) observes that about two-thirds of the municipalities had an approved plan by mid-1990s, but that most strictly emphasized "land-use and zoning and lacking any strategic guidance in terms of development policy."

While most scholars abide to this recurrent narrative, other evidence suggests some form of planning did guide urban development over the decades. An inventory conducted by Lôbo (1995) to the plans developed and approved by 1960 indicates that 
more than 230 out of 330 towns had an approved or partially approved plan. Also, as Pires (2001, 2005) and Sá (2002) observed, during the 1980s and 1990s, municipalities often used non-approved plans to guide urban development. These observations contradict, at best, claims regarding the lack of planning and prompt us, at least, to question the 'unplanned country' idea.

Underlying scholars' lack of formal planning argument is the very 'modern' but deceptive assumption that only formal, legally binding plans will induce orderly physical growth. From where they stand, the absence of plans leads to chaotic urban growth, due to discretionary decision-making and behavior. Moreover, scholars assume it is improbable that the desired order will be achieved unless these plans cover absolutely every inch of the territory and entail a comprehensive understanding of it. Finally, they reckon that formal planning is to be carried by state agents willing to promote the public interest under the advice of unbiased, expert professionals. As pointed above by Gunder and Hillier (2009), this is seldom the case. Yet, Portuguese urban scholars have mostly relied on explanations of 'lack' to make a case for the 'unplanned' nature of urban development.

Scholars tend to place explanations for the lack of formal planning in the domain of politics. They point mainly at the central government's inability or unwillingness to enable an effective planning system. One of the explanations for this refers to the political instrumentalization of planning right from its inception in the dictatorship regime. For instance, Lôbo (1995: 35) suggests that the 1934 Act intended to create an urban image consistent with the conservative and paternalistic tenets of the regime. In a study of the history of urban planning and policy in Lisbon during the dictatorship period, Silva (1994) contends that the regime's ideology limited the capacity of municipalities to conduct planning at the local level.[4] This was achieved, as many other scholars also suggest, by a strategy of authoritarian, centralized control by the central government over the municipalities (Ferreira, 1983, 1987; Silva 1994), a strategy that remained after 1974 as the democratic political system consolidated (Carter and Silva, 2001). Gonçalves (1986) suggests centralization was a way for the dictatorship to keep the local bourgeoisies aligned under the tenets of the corporatist regime. Pinho (1997: 2039), looking into the bargaining possibilities offered by the Portuguese planning system, observes a similar discretionary attitude on the part of the municipalities after 1974. Ferreira (2005), probably drawing on his experience as a public official, provides a relentless critique of the country's central administration in current times. He maintains that several factors have undermined the ability to manage urban development, namely: a fragmented and inflexible legal framework unsuitable for strategic planning; an enduring disorganization of a sector-based central administration, with opaque procedures and managing officials and professionals with inadequate training; a lack of sense of mission regarding the public interest due to continuous political instability at ministerial levels and the predominance of informal and clientelist behaviors; and a consequent lack of leadership and accountability (ibid.: 42-56).

Another common explanation for the lack of formal planning is the lack of technical and financial resources to conduct sound planning. Lôbo (1995: 39) concluded that the 1934 Act's requirements for plan development constituted an extremely ambitious endeavor. She suggests that the expectations of the central government went from a 
"situation of almost total absence of [plans] to demanding [the development of] more than four hundred plans, within a mandatory timeframe of three years" (ibid.: 39-40). Other scholars identify the persistence of similar hurdles in the following decades. Pires (2005) maintains that, until the 1970s, the lack of political and financial autonomy and technical capacities experienced by municipalities prevented them from having formally approved plans to control urban development. Some sources indicate that, by the early 1980s, many municipalities continued to lack the necessary cartographic resources, the financial resources to acquire them and the expertise to use existing maps, many of which were unavailable for parts of the country or surveyed at inappropriate scales (Pedrosa et al., 1986: 224-225). There is a general consensus among scholars that only the vast funding influx after Portugal's accession to the EEC addressed this state of affairs, contributing to an increase and transformation of the nature of planning (Carter and Silva, 2001; Pires, 2001, 2005; Balsas, 2006; Cardoso and Breda-Vázquez, 2007).

Finally, some scholars tend to notice the lack of concern for planning in the public interest, suggesting a lack of planning culture among mayors, real estate developers and citizens. For instance, Ferreira (2005: 44) explains that another reason for the persistent disorder is the "deficit of urban culture in the portuguese society, in its sociological and generational matrix," an explanation also shared by Carter and Silva (2001: 347). Schmidt (1999; 2007) talks about the dangerous connections between real estate developers and mayors, reproving the latter for not understanding that sustainable development cannot be achieved without planning. Carter and Silva (2001: 349) suggest this sort of understanding facilitated private developers' free reign, especially until the 1970s, who developed land where it was cheaper - "on the urban fringes, where there [were] no urban facilities or public transport networks" (see also Carvalho, 2003).

\subsection{Deepening scholarly engagement with urban and social theory debates}

The sparing engagement of scholars' explanations with existing debates in urban and social theory stands out in the review of the diverse literature presented thus far. It is undeniable that many or all of the explanations above may have had their share in the dynamic processes that shaped Portuguese urban development. Yet, I am left with the sense that each explanation stands very much as a definitive 'truth' about the peculiarity of the Portuguese city. With notable exceptions identified below, obliviousness regarding related literature is noticeable (e.g. Soares' contention about planned and unplanned 'dispersion' raised earlier). However, acknowledging existing research and literature would signal scholars' understanding of explanations as temporary ways of organizing evidence about phenomena, not as definitive 'truth'. It would also carve a place for the Portuguese city in urban scholarship.

Revealing mostly a positivistic approach, the explanations take for granted, naïvely or just simplistically, that the 'why' of planning is, at any time and for all actors, a rational and apolitical search for a unitary public interest. While it is clear that most Portuguese urban scholars favor a political understanding of planning, they seem to wish, somewhat paradoxically, that the modern depoliticized vision prevailed. They seem to ignore Flyvbjerg's (1998) much lauded work on power- and special interest-dominated accounts of planning in Denmark or the micro-study of U.S. planners' activities in the 
face of power by Forester (1989). Or, when reproaching as un-modern the prevalence of interested relationships between municipalities and real estate developers, scholars are seemingly unaware of similar reports found in U.S. 'growth machines' (Logan and Molotch, 1987) or 'urban regimes' (Stone, 1989) theories. Where Portuguese scholars see a lack of modernity, these authors see the expression of conditions of capitalist urban production.

One of the things that the politically based explanations seemingly miss is a more profound and explicit discussion relating the nature of the Portuguese urban condition with the role of the state and planning, the exercise of government and what it entails. In a way, the accounts reflect what Roy (2004) sees as the 'aestheticization' of patterns of urban development as mere physical forms, instead of expressions of a particular political economic order (e.g. access to decent housing and appropriate salaries). Engagement with social theory and, more particularly, the role of the state in disciplining urban development are not absent from Portuguese scholarship. For instance, providing a Marxist-inspired interpretation of the dynamics of the illegal housing sector in Portugal up to the 1980s, Cardoso (1983a: 2-3) notes that "the question of illegality itself is important only from the limited viewpoint of the institutions with formal police powers over housing development." He suggests that defining something as 'illegal' is then somewhat problematic. What we need to be looking for instead, he argues, is a deeper understanding of the dynamics of governing: "why and how landowners, developers and builders alike avoid planning and building regulations and what has the State done (if anything) about the situation" (ibid.: 3). Unfortunately, the questions raised and addressed by Cardoso in his work stand conspicuously alone in a landscape of Portuguese urban scholarship dominated by the 'unplanned country' narrative ( $c f$. Ruivo (2000) on the relationships between central and local levels of government in which urban development figures prominently).

Moreover, the explanations provided by scholars tend to assume that planning is to be conducted by a state apparatus willing to exert discipline and concerned with redistributive policies for the universal well-being of its citizens. For instance, explanations that planning during the dictatorship was politically instrumentalized and lacked disciplining power, presume that the regime was interested in a fair, redistributive and transparent process, as well as in disciplining developers for that sake. However, in another work on state's housing policy, Cardoso (1983b: 31-32) argues that the focus of the dictatorship was not redistribution, but a stabilization of the place that each social group had in the corporate regime (see also Ferreira, 1983, 1987). Similar discussions about the role and nature of the state in regard to urban development after 1974 and how ideologically difficult it was for the regime to exert the disciplinary control that planning required are few and far between ( $c f$. Cerezales, 2003; Pinto, 2008). To my knowledge, no one has conducted an empirical study and a theoretical reflection on the relationship between the nature of planning and the political instability between 1976 and 1987, when Portugal had ten different national governments, run by eight different prime-ministers, and eleven different ministers responsible for urban planning. Or, no one seems to have empirically and theoretically researched the commonly accepted observation that planning changed with the accession to the EEC, discussing how that was connected with a particular view of modernization, democratic consolidation and, ultimately, state-building. What I am suggesting here is that if we are 
to explain the lack of formal planning through a lack of willingness to plan, we must question, empirically and theoretically, what planning meant for each regime and which planning was desirable and possible at each moment in time.

The dominant view of power as top-down authority implied by these explanations is also a reflection of how impervious Portuguese urban scholarship has remained to Foucauldian or Gramscian analyses. One way in which this absence is displayed is the periodization of the evolution of the planning system according to regime changes: (1) the dictatorship period (1926-1974); (2) post democratic-revolution (1974-1986); and (3) post accession to the EEC (1986-present). The underlying assumption of this subdivision is that when the nature of the state changes, so does the ideology and practice of planning. In other words, the state figures as a separate entity from the market and civil society, being responsible for determining and conducting planning and shaping urban development, mostly through legislation and legal regulations. Gramsci-inspired inquiries have the potential to bring out the paradox of this tri-partite separation, especially between the spheres of the state and civil society. For instance, one line of inquiry could reflect on strategies of hegemony, consent and dominance mobilized by the Portuguese state after 1974 to address clandestine settlements. Another possible study could take on Mitchell's (1997) Gramsci-inspired study of Hong Kong Chinese immigrants' 'monster houses' in Vancouver - in which she showed the tensions between elites, representative democracy and the nature of public space. A similar study in the Portuguese context could focus on expert views of self-built housing and elucidate their role in shaping discourse, practices and legalistic visions of how to deal with informal housing. It would also cast light on their role in shaping the 'unplanned country' idea itself. The insensitivity to issues of inequality or class domination is also apparent in the conspicuous dearth of empirical works addressing race, ethnicity or gender in the history of urban planning and development in Portugal (in planning literature, a notable exception are the works on social justice by Cardoso and Breda-Vázquez (2007, 2009)). This reflects the overlooking of Foucault-inspired views on subjectivity, power and governmentality, as well as other strands of theory, such as postcolonialism, gender studies or subaltern studies. Scholars inspired by Foucault's works pay attention to other forms of governing society and the physical space of the city. Some, like Boyer (1983), outline complex genealogies of the planning apparatus and its sets of professional discourses, government bodies and agencies, laws and regulations, conceptual and procedural techniques and claims to truth and expertise) Others, like Flyvbjerg (1998), seek to deconstruct different rationalities of power and planning process in modern democracies. Others yet cast struggles over planning issues as a matter, not of interest-based politics, but as ways of challenging state-defined subjectivities (Allen, 1996).

Whether Portuguese scholars are to choose Marxist, Gramscian, Foucauldian, Lacanian, postmodern or other approaches, a deeper theoretical engagement with research and debates in urban and social theory is only desirable. It will also be the way to move beyond (and potentially debunk) the idea of Portugal as an 'unplanned country'. 


\subsection{The creation of a field of expertise, authority and appropriateness}

In the survey of the literature provided thus far, we hear what scholars - the elite of planning practitioners, policymakers, academics, and opinion-makers - think of the Portuguese urban experience, as if they were detached observers. They stand as Weber's (1946) cadre of professionals of the modern state, servicing the public interest with a legitimacy set outside of politics by their claims to expertise and scientific neutrality. Yet, most of these scholars have been at the forefront of shaping urban planning, policy and practice and of creating the expertise to fix the 'disorder' of the Portuguese city.

Foucauldian and Gramscian analyses found wanting could also elucidate how the idea of the 'unplanned country' connects with the emergence of these scholarly and professional elites. Gramsci (1971) argued that intellectuals are not such neutral providers of unquestionable truths and expertise, because they are deeply embedded in the structures of society. They are instrumental to the ascendance and maintenance of a ruling class in power, by providing them with the "thinking and organizing" necessary to govern masses by consent. Foucault (1978) notes that this consent is more like a mode of self-governing, where certain discourses of truth - such as that of the 'unplanned country' - are widely imposed by specific groups claiming expertise (technical, aesthetic and social) over the issue to be governed.

A detailed empirical study of the role played by planning practitioners in shaping the apparatus and discourse of planning in Portugal, at least since the 1960s, could illuminate how the incontrovertible 'truth' of an 'unplanned country' emerges in tandem with their attempt at carving out of a space of professional and intellectual legitimacy. Such a genealogy must take on a task this article leaves untouched: to unearth a rich understanding of the different professional fields engaged in planning the Portuguese city and of the personal motivations and the political and academic projects held by all those who later fed the 'unplanned' narrative through their writings and their practices.

Whether this turns out to be the case or not, it is only fair to acknowledge here the contribution that planning practitioners' authoritative discourse had in transforming the material conditions of millions of Portuguese over decades. But such recognition can not overshadow our scholarly responsibility to question whether the 'unplanned country' discourse continues to be useful or if, with the benefit of hindsight, it is now a constraining element forsaking alternative futures for the Portuguese city.

\section{How the idea gets built: empirical shortcomings}

Now that we have an overview of what the idea of Portugal as an 'unplanned country' entails, the justifications given for it, and the theoretical shortcomings they are based on, we must question how urban scholarship generates the intellectual construct itself. In other words, we must question the empirical methodologies underlying the production of the intellectual construct. In this section, I survey two empirical shortcomings I see underlying the construction of the 'unplanned country' idea, namely: (1) methodological conflations, especially between planning legislation and planning practice; and (2) the dominance of thin and pragmatic empirical studies to support existing observations. 


\section{Methodological conflations}

One way in which scholars construct the consensus over the 'unplanned country' idea is through its repetition. Reading through articles published both nationally and internationally on diverse aspects of Portuguese urban development and planning, we commonly finding a section providing a brief history of planning in Portugal. This account of the Portuguese planning context is ubiquitously similar across publications, as the story of disorder, lack of formal planning, centralism, political instrumentalization and inadequate expertise repeats itself with only minor variations (e.g. Salgueiro, 1992; Correia, 1993; Silva 1993; Pinho, 1997; Carter and Silva, 2001; Lobo, 2001; Pires, 2001, 2005; Carvalho, 2003; Ferreira, 2005; Balsas, 2006; Cardoso and Breda-Vázques, 2007; Domingues et al., 2007; Oliveira and Pinho, 2008; BredaVázques et al., 2009).

One notable feature of this repetitive story is its chronological narrative describing successive planning Acts and official policies, often standing for what planning was in real practice. This is theoretically problematic because it denotes the lack of engagement with urban and social debates mentioned above. Methodologically, it shows an unreflective conflation of state intentions (as represented by planning legislation, policies or plan documents itself) and planning practice (i.e. what planners do in their daily lives, how decisions get made and the micro-study of implementation processes).

For instance, Oliveira and Pinho (2008) set out to review the impact of fifteen plans on the urban form of Lisbon and Porto between the late-1870s and the 2000s. To frame their later analysis of the plans, they spend the first part of their article describing the successive planning Acts. They reference what each legislative piece requires a plan to include, or what plan documents were composed of once concluded. They proceed to discuss the intentions of the experts involved in planning both cities and the design traditions that influenced them. They also review the stated objectives defined in the plans and contrast proposals between plans. They describe for specific decrees and regulations the land use control instruments made formally available to municipalities (e.g. compulsory acquisition powers). In a few instances, the authors shyly venture into the politics of plan development and implementation. In sum, we get a very detailed account of what each legislation piece or plan intended to achieve regarding the urban form of the two cities. But we are left in the dark regarding the politics of how (and whether) each got implemented, what sorts of land use controls (if any) municipalities used, and how urban form was shaped as a result.

I detail Oliveira and Pinho's article not to belittle their work, but to illustrate a style of reporting dominant in Portuguese urban scholarship and to highlight their methodological shortcomings in expanding our knowledge of urban phenomena.[5] This type of research is necessary and relevant to an understanding of the imaginations of planners and policymakers in conceiving the future of cities (albeit I suspect the authors have more pragmatic inclinations in their work). Moreover, in a recent article proposing a methodology for plan evaluation (Oliveira and Pinho, 2009), they provide an evaluation of different features of the processes and practices leading up to two municipal plans. I use their work simply as an illustration of a style of reporting 
dominant in Portuguese urban scholarship and to highlight their methodological shortcomings in expanding our knowledge of urban phenomena. As planning scholars (and practitioners) know only too well, many of plans' stated intentions fail to reach implementation. In order to further our understanding of implementation of plans (and other urban policies), scholars must engage in micro-studies of implementation and other ethnographic and comparative research that brings out the inner workings of the planning process, disclose the genealogies of planning agendas and objectives, power relationships, and their actual impacts on the fabric of the city.

Another case of methodological conflation is when scholars use the case of urban planning and development in the municipality of Lisbon - and, in fewer cases, of Porto - to represent the planning context for Portugal as a whole. This methodological move is understandable, for planning activity in both municipalities was more prolific and well documented than anywhere else in the country. However, this is another problematic case in which the tree is taken for the forest. As noted by scholars for the dictatorship period (e.g. Gonçalves, 1986; Silva, 1994), planning and urban development in Lisbon and Porto were carried out under exceptional legal regimes. Hence, it is unadvisable to take their experiences to stand for the rest of the country without acknowledging the comparative shortcomings. This is even more relevant if we consider that much of the urban development usually referred to as 'unplanned' took place in neighboring municipalities.

A final methodological conflation resides in the use of empirically weak, commentarystyle publications to support the idea of Portugal as an 'unplanned country'. For some of the works cited in this article it is unclear how scholars support their observations leading up to the idea of the 'unplanned country' and its explanations. Some works fall short of clarifying the sources and the methodologies of data collection and analysis and the derived findings that serve to support arguments made (e.g. Carter and Silva, 2001: 363-366; Pires, 2001). I suspect that many of the works rely heavily on the personal experiences of their authors as policymakers, public officials or planners involved in the plans they report on (e.g. Ferreira, 1999, 2000, 2005; Soares, 2002). For others still, the boundary between activism and scholarship is somewhat blurred (e.g. Schmidt, 1999, 2007).

\section{Empirically thin and pragmatic studies}

The methodological conflations observed are ultimately related to the few empirically and theoretically robust studies conducted about topics relevant to the understanding of urban planning and development in Portugal. Some of the empirically robust studies are thinly developed at the theoretically level mostly due to their descriptive or pragmatic focus. Four cases in point are the work by Carvalho (2003) providing an illuminating report on urban planning in sixteen municipalities based on an extensive survey to municipal services and some direct observation; the outstanding historical work provided by Lôbo (1995) on plans developed during the first decades of the dictatorship regime; the thorough review of urban legislation provided by Lobo (2001); and the heavily documented study of the functional and morphological patterns of Portuguese cities provided by Salgueiro (1992). 
The shortage of empirically and theoretically robust studies, especially published and available to a wider audience, prompts many scholars to rely, often uncritically, on existing studies despite their apparent shortcomings. One concrete example is the constant citation of the work of Gonçalves (1989) on the historical evolution of planning legislation in Portugal since the mid-nineteenth century. This publication results from a paper presented by the author in 1988 at a training course for public officials. The methodology leading up to the interpretations Gonçalves provides is conspicuously absent. Gonçalves does warn the reader that his account is highly personal and resulting from a lack of previous studies on the subject. He does not shy away from providing politicized views of the evolution of planning legislation. Right up front, he insinuates that the 1980s planning law descended from the "complete governmentalization of urban legislation" in the dictatorship regime (ibid.: 1). His characterization of the legislative evolution relies on a mixture of enunciation of contents of each law and regulation; public expressions of the state of affairs by architects or public officials; and his own personal opinions on the intentions and achievements of laws and regulations. Gonçalves concludes that, until 1971, not a single plan was formally approved (ibid.: 33). As showed earlier, evidence exists to question this contention. However, Gonçalves' claims appears repeated in Balsas (2006), Carter and Silva (2001: 248), Pires (2001: 183; 2005: 239) and in Cardoso and Breda-Vázquez (2007: 392) who cite Pires (2005). Despite its methodological shortcomings, this claim serves invariably to illustrate the lack of planning in Portuguese cities up to the 1970s.

\section{A Research Agenda for Portuguese Urban Studies}

I started this article by pointing out the prevalence of the idea of the 'unplanned country' in existing scholarship on the urban condition of the Portuguese city, its planning and pattern of urban development. I argued that more than a constitutive fact or truth about the Portuguese urban condition, the 'unplanned country' operates as an intellectual and discursive construct that organizes perceptions of chaos, disorder and underdevelopment in the context of modernity. I relied on the words of key scholars in Portuguese urban planning and policy to illustrate first-hand their bleak reading and derogatory tone in characterizing the Portuguese city as 'not quite yet' modern and in developing explanations that cast practices and behaviors as equally un-modern. Throughout the text, I provided counterpoints to the assertions made, relaying scholars' observations back to research done elsewhere (or in Portugal), in the hope it would raise eyebrows and further inquisitive endeavors. I suggested that for the research on the Portuguese city to successfully carve a space of relevance within current urban studies debates, scholars must engage widely, and more deeply, with urban and social theory beyond the dominant and implicit positivistic approach. I also suggested that more robust and diverse empirical research is needed, so as to overcome existing methodological shortcomings and enlarge the pool of studies upon which scholars can build their own research. I noted that such, empirically and/or theoretically, robust studies do exist in Portuguese urban scholarship but are few and far between.

My intent with this article has been to expose the way in which the 'unplanned country' idea emerges and to question its theoretical and empirical underpinnings. I did not seek to assess if it correctly assesses the nature of Portuguese urban development and 
planning since the 1930s. While I suspect some scholars will find relevance in qualifying the nature of such development, I rather want to focus attention on deepening our knowledge about the Portuguese city, its patterns, processes and practices of urbanization and planning. I follow here the view of Portas et al. who note that, in studying the Portuguese city, "we tend to evaluate badly what we know less about... by defect, we forget about it [;] by excess, we demonize it... as an image of disorder, of waste, of chaos" (2003: 15). For that reason, they maintain that there is an open field for research on the Portuguese city created by "the lack of knowledge, [the] insistence on worn out models and solutions, rushed evaluations, [the] simplistic import of problems and solutions studied and practiced elsewhere" (Portas et al., 2003: 21).

In this concluding section, I propose a preliminary outline for future research that seeks to redress the empirical and theoretical imbalances identified in existing scholarship. Far from providing a definitive guideline, I hope that scholars studying the Portuguese city take the following five interrelated lines of inquiry and further discuss, improve on them in undertaking new, exciting research and intellectual pursuits.

\section{What Urban Development? Questioning the 'Unplanned Country'}

Research under this line of inquiry focuses on a thorough scrutiny of the 'unplanned country' assertion from the point of view of development itself: where urban development took place; how much development previously accounted for in legally and non-legally binding plans occurred; and how much development projected in plans actually happened. This includes comparative and cross-section studies of urban development and planning documents, supported by GIS technologies. Research should favor municipalities other than Lisbon and Porto. Findings should be conceptualized in contrast with similar research on urbanization and suburbanization processes elsewhere. Moreover, findings should also be conceptualized in the context of discussions of modernity and urban informality.

\section{What Planning? The Governing of Urban Development}

Research under this line of inquiry focuses on understanding the apparatus of Portuguese planning: what planning meant at different points in time; which techniques and technologies agents deployed; and what planning conducted in practice looked like. A similar line of inquiry should be conducted for urban policy. Research can draw on such methodological approaches as histories, genealogies and, for more recent cases, micro-studies and ethnographies of planning and policymaking practice. This research provides us with a deeper understanding of what planning was (and is), instead of what it ought to be.

\section{What Discipline? Planning and the State}

Following from the two previous lines of inquiry, research under this topic seeks to reflect on how processes and patterns of urban development and the apparatus of planning and its practice relate to the state. This entails research about the nature of authority, legitimacy, and consent; of legalities, illegalities and extra-legalities; of separations between state, market and civil society; of the nature of the modern, liberal democratic regime under which rights to development and planning come to be defined; studies of planning and development beyond the state, by private developers themselves, and their own (alternative) notions of modernity; and the interactions with 
supra-national institutions and transnational processes such as globalization. This type of research can expand on existing Marxist-inspired, political economy studies of past capitalist accumulation processes, or under recent conditions of neoliberalization. But it can also cover, amongst other approaches, the Foucauldian and Gramscian-inspired examples mentioned above, or extend to postcolonial inspirations wherever a study of planning in Portugal and its (ex)colonies might be conducted.

\section{What Planners? Elites and Urban Development}

The fourth line of research zooms in on the role played by planning practitioners in thinking about, conducting, and organizing a professional field for planning. These studies range from detailed surveys of the municipal body of technicians available over time throughout the country and their professional training and expertise, to critical histories and genealogies of the professional field and its contribution to shape the 'unplanned country' idea. This reflection on planning practitioners' roles in the construction of the Portuguese city, their conceptual approaches, biases, and achievements is of relevance to enlarge the pool of experiences that theory of planning practice draws from.

\section{5: Which Urban Citizens? Race, Ethnicity, Gender and Class in the Portuguese City}

The final line of inquiry concerns the multiple 'Others' absent from accounts of Portuguese urban development and planning. These studies focus on the role of planning and patterns of urban development in bringing about diverse processes, such as: socio-spatial divisions based on class distinction and privilege; social reproduction and social justice; multiple identities and subjectivities; uneven citizenships; or participatory democracy. Two possible studies come to mind: one concerns the processes of urbanization that followed the return of Portuguese and African immigrants to mainland Portugal after the 1970s decolonization; another study concerns the critical analysis of urban practices in immigrant dominated neighborhoods.

Finally, it is my hope that, in using the benefit of hindsight available to me, this article contributes to an introspection about the development of the field of planning in Portugal, the themes and agendas it has progressed, and its strengths and limitations. It is also my hope that this reflexive exercise can help scholars of the Portuguese urban experience, as well as scholars of other 'silenced' experiences, to contribute to an epistemological renewal that blasts open the very idea of an all-encompassing 'EuroAmerican' urban experience.

\section{Notes}

[1] I adopt here the view of Lôbo (1995) that the passing of the 1934 General Urbanization Plan Act marked in Portugal the generalization of modern planning (i.e. development control through building and land use controls). My analysis excludes prior exercises in the organization of city space analyzed by other authors ( $c f$. Salgueiro, 1992; Balsas, 2006). 
[2] The documentary series was based on an extensive research project coordinated by Barreto (1996) on social change in Portugal between 1960 and 1995.

[3] See Cardoso (1983a; 1983b) for an early study of housing between 1960 and 1980 and a clarification of the term 'clandestine' in the Portuguese context and its relationship with informal settlements.

[4] He reckons that economic and fiscal crises endured by the Portuguese state at different moments in time operated as the structural background upon which the inefficiencies of the planning system rest (Silva 1993; 1994). Despite its apparent relevance to a broader understanding of the conditions of modernity in Portugal, this explanation finds little interest among scholars.

[5] In fact, in a recent article proposing a methodology for plan evaluation, Oliveira and Pinho (2009) provide an evaluation of different features of the processes and practices leading up to two municipal plans.

\section{Acknowledgements}

I thank the referees who reviewed this article, whose comments prompted me to embark on this reflexive journey of Portuguese urban scholarship. This article benefited from fruitful intellectual exchanges with Tiago Castela, Ricardo Cardoso and Marcia C. Schenck. Research for this article was initially conducted with the support of Fundação para a Ciência e a Tecnologia, Portugal, under the European Union's POCI 2010 (Bolsa $\mathrm{SFRH} / \mathrm{BD} / 12396 / 2003)$. The article was written during my first years at the University of Oxford. My colleagues there - Line Bonneau, Lisa Stampnitzky, Malte Ziewitz and Steve Rayner - provided valuable comments on earlier versions.

\section{References}

Allen, J. (1996) Our town: Foucault and knowledge based politics in London. In S.J. Mandelbaum, L. Mazza and R.W. Burchell (eds.) Explorations in planning theory. Center for Urban Policy Research, Rutgers, New Brunswick.

Balsas, C. (2006) Evolución histórica de la planeación de ciudades en Portugal. Revista EURE XXXII.97, 81-95.

Barreto, A. (ed.) (1996) Situação social em Portugal, 1960-1995, Instituto de Ciências Sociais, Universidade de Lisboa, Lisboa.

Barreto, A. and J. Pontes (2007) Mudar de vida: o fim da sociedade rural. Portugal: um retrato social. RTP, Rádio e Televisão de Portugal, Portugal.

Boyer, M.C. (1983) Dreaming the rational city: the myth of American city planning. MIT Press, Cambridge.

Breda-Vázquez, I., P. Conceição and R. Fernandes (2009) Partnership diversity and governance culture: evidence from urban regeneration policies in Portugal. Urban Studies 46.10, 2213-2238. 
Cardoso, A.S. (1983a) The illegal housing sector in Portugal - "Bairros Clandestinos". University of Reading, Reading.

Cardoso, A.S. (1983b) State intervention in housing in Portugal, 1960-1980. Ph.D. University of Reading.

Cardoso, R. and I. Breda-Vázquez (2007) Social justice as a guide to planning theory and practice: analyzing the Portuguese planning system. International Journal of Urban and Regional Research 31.2, 384-400.

Cardoso, R. and I. Breda-Vázquez (2009) The institutionalization of just decision making: analyzing planning practice in Portugal. Environment and Planning $C$ 27.3, 413-432.

Carter, N. and F.N.D. Silva (2001) Recent changes in territorial planning and the system for controlling urban development in Portugal. Town Planning Review 72.3, 341-370.

Carvalho, J.D. (2003) Ordenar a cidade. Quarteto Editora, Coimbra,.

Cerezales, D.P. (2003) O poder caiu na rua: crise de Estado e acções colectivas na revolução Portuguesa 1974-1975. Imprensa de Ciências Sociais, Lisboa.

Chakrabarty, D. (2000) Provincializing Europe: postcolonial thought and historical difference. Princeton University Press, Princeton.

Correia, F.N. (2003) Levar a Expo ao país todo (entrevista a Francisco Nunes Correia). By Manuel Graça Dias and Ana Vaz Milheiro. Jornal Arquitectos 209, 9-17.

Correia, P. (1993) Políticas de solos no planeamento municipal. Fundação Calouste Gulbenkian, Lisboa.

Domingues, Á., N. Portas and T.S. Marques (2007) Portugal: urban policies or policies with an urban incidence? In L. van den Berg, E. Braun and J. van der Meer (eds.) National policy responses to urban challenges in Europe. Ashgate, Aldershot.

Ferreira, A.F. (1999) Para uma política de cidades. Sociedade e Território 29, 4-15.

Ferreira, A.F. (2000) O insustentável desperdício urbano. Sociedade e Território 30, 45.

Ferreira, A.F. (2005) Simplificar o Planeamento e Gestão do Território. Sociedade e Território 39, 4-5.

Ferreira, V.M. (1983) A Lisboa do Império e o Portugal dos Pequeninos: estrutura fundiária e politica urbana de Lisboa, anos de 1930-40. Análise Social XIX.3-45, 693-735.

Ferreira, V.M. (1987) A cidade de Lisboa: da capital do império a centro de metrópole. Dom Quixote, Lisboa.

Flyvbjerg, B. (1998) Rationality \& power: democracy in practice. The University of Chicago Press, Chicago.

Forester, J. (1989) Planning in the face of power. University of California Press, Berkeley.

Foucault, M. (1978) Governmentality. In P. Rabinow and N. Rose (eds.) The essential Foucault: selections from The Essential Works of Foucault, 1954-1984. The New Press, New York.

Gastaut, Y. (2004) Les bidonvilles, lieux d'exclusion et de marginalité en France durant les trente glorieuses. Cahiers de la Méditerranée [Online]. Available at: http://cdlm.revues.org/index829.html [Accessed 11 November 2010].

Gonçalves, F. (1986) A propósito dos Planos de Urbanização do Estado Novo: projectos urbanísticos ou regulamentos policiais? Sociedade e Território 4, 92-115. 
Gonçalves, F. (1989) Evolução histórica do direito do urbanismo em Portugal (18511988). LNEC, Lisboa.

Gramsci, A. (1971) The formation of the intellectuals. In Q. Hoare and G.N. Smith (eds.) Selections from the Prison Notebooks. Lawrence and Wishart, London.

Gunder, M. and J. Hillier (2009) Planning in ten words or less: a Lacanian entanglement with spatial planning. Ashgate, Aldershot.

Hajer, M. (1993) Discourse coalitions and the institutionalization of practice: the case of acid rain in Great Britain. In F. Fischer and J. Forester (eds.) The argumentative turn in policy analysis and planning. Duke University Press, Durham.

Hall, P. (2000) Cities of tomorrow: an intellectual history of urban planning and design in the twentieth century. Blackwell, Oxford.

Harris, R. (1999) Unplanned suburbs: Toronto's American tragedy, 1900 to 1950. Johns Hopkins University Press, Baltimore.

Hervo, M. and M.-A. Charras (1971) Bidonvilles: l'enlisement. François Maspero, Paris.

Lobo, M.D.C. (2001) Administração urbanística: evolução legal e sua prática. IST Press, Lisboa.

Lôbo, M.S. (1995) Planos de Urbanização: a época de Duarte Pacheco. Faculdade de Arquitectura da Universidade do Porto/DGOTDU, Porto.

Loeb, C.S. (2002) Entrepreneurial vernacular: developers' subdivisions in the 1920s. Johns Hopkins University Press, Baltimore.

Logan, J.R. and H.L. Molotch (1987) Urban fortunes: the political economy of place. University of California Press, Berkeley.

Mitchell, K. (1997) Conflicting geographies of democracy and the public sphere in Vancouver BC. Transactions of the Institute of British Geographers 22.2, 162179.

Nicolaides, B.M. (2002) My blue heaven: life and politics in the working-class suburbs of Los Angeles, 1920-1965. University of Chicago Press, Chicago.

Oliveira, V. and P. Pinho (2008) Urban form and planning in Lisbon and Oporto planning. Planning Perspectives 23.1, 81-105.

Oliveira, V. and P. Pinho (2009) Evaluating plans, processes and results. Planning Theory \& Practice 10.1, 35-63.

Pedrosa, F.M.T., A.D.S. Pedrosa and B.D.S. Marques (1986) Notas e recensões: I Seminário Nacional sobre Cartografia Temática e Cadastral. Revista da Faculdade de Letras - Geografia (I Série) II, 222-226.

Pinho, P. (1997) Local planning and national environmental assessment procedures: the developer's mitigated role in disjointed negotiation processes. Urban Studies 34.12, 2037-2052.

Pinto, P.R. (2008) Urban social movements and the transition to democracy in Portugal, 1974-1976. The Historical Journal 51.4, 1025-1046.

Pires, A.D.R. (2001) Breaking the ties with the master plan: spatial strategic plans in Portugal. In L. Albrechts, J. Alden and A.D.R. Pires (eds.) The changing institutional landscape of planning. Ashgate, Aldershot.

Pires, A.D.R. (2005) The fragile foundations of European spatial planning in Portugal. European Planning Studies 13.2, 237-252.

Portas, N., Á. Domingues and J. Cabral (eds.) (2003) Politicas urbanas - tendências, estratégias e oportunidades, Fundação Calouste Gulbenkian, Lisboa. 
Rabinow, P. and N. Rose (1994) Introduction: Foucault today. In M. Foucault, P. Rabinow and N. Rose (eds.) The essential Foucault: selections from Essential Works of Foucault, 1954-1984. The New Press, New York.

Rein, M. and D.A. Schön (1993) Reframing policy discourses. In F. Fischer and J. Forester (eds.) The argumentative turn in policy analysis and planning. Duke University Press, Durham.

Robinson, J. (2006) Ordinary cities: between modernity and development. Routledge, London.

Roy, A. (2004) Transnational trespassings: the geopolitics of urban informality. In A. Roy and N. Alsayyad (eds.) Urban informality: transnational perspectives from the Middle East, Latin America, and South Asia. Lexington Books, Lanham.

Roy, A. (2009) The 21st-century metropolis: new geographies of theory. Regional Studies 43.6, 819-830.

Sá, M.F.D. (2002) Planos operativos de escala intermédia: caracterização técnica e arquitectónica. Sociedade e Território 33, 46-56.

Salgueiro, T.B. (1992) A cidade em Portugal: uma geografia urbana. Edições Afrontamento, Porto.

Sandercock, L. (2003) Cosmopolis II: mongrel cities of the 21st century. Continuum, London.

Santos, B.D.S. (1994) Pela mão de Alice: o social e o político na pós-modernidade. Edições Afrontamento, Porto.

Schmidt, L. (2003) Ambiente e Ecrã. Emissões e Demissões no Serviço Público Televisivo. Imprensa de Ciências Sociais, Lisboa.

Schmidt, L. (2007) País (in)sustentável: ambiente e qualidade de vida em Portugal. Esfera do Caos Editores, Lisboa.

Scott, J.C. (1998) Seeing like a State: how certain schemes to improve the human condition have failed. Yale University Press, New Haven.

Sennett, R. (1970) The uses of disorder: personal identity and city life. Yale University Press, London.

Silva, C.N. (1993) As determinantes económicas e políticas do planeamento municipal em Portugal. Finisterra XXVIII.55-56, 23-58.

Silva, C.N. (1994) Politica urbana em Lisboa, 1926-1974. Livros Horizonte, Lisboa.

Soares, L.B. (2002) A realidade incontornável da dispersão. Sociedade e Território 33, 123-129.

Stone, C.N. (1989) Regime politics: governing Atlanta 1946-1988. University Press of Kansas, Lawrence.

Ward, S.V. (2002) Planning the twentieth-century city: the advanced capitalist world. John Wiley \& Sons, Chichester.

Weber, M. (1946) From Max Weber: essays in sociology. In H.H. Gerth and C.W. Mills (eds.) Oxford University Press, New York. 